\title{
Social Inequality as Trauma During the Covid-19 Pandemic
}

\author{
Polikarpova E. V. ${ }^{1}{ }^{*}$ Shipelik O. V. ${ }^{1}$ Krylova I.V. ${ }^{2}$ \\ ${ }^{1}$ Southern Federal University, Rostov-on-Don 344006, Russia \\ ${ }^{2}$ Liceum - boarding school of the children and teenagers person complex formation, Gelendzhik 353484, Russia \\ ${ }^{*}$ Corresponding author. Email: nellenele@gmail.com
}

\begin{abstract}
The article is devoted to the analysis of one of the global problems of humanity - the problem of social inequality. The COVID-19 pandemic, being an infectious trauma, destabilized economic development, exacerbated social inequality in the world, deepened the social trauma in post-Soviet Russia, formed from the collapse of the industrial system, and the transition to the export of raw materials to foreign markets. The conceptualization of approaches to this problem will make it possible to comprehend the measure of the balance between saving the economy, saving people's lives, and the future post-pandemic development of Russia. The article analyzes the steps of the Russian government to assist various categories of the population during the period of restrictions, forced unemployment. It is considered that only by abandoning the neoliberal course, it is possible to revive social justice, restore the country after a pandemic, and turn Russia into a high-tech power. The result of the study shows that it is possible to solve the problem of social inequality in Russian conditions by choosing the paradigm of planned methods of the country's development.

Keywords: pandemic COVID-19, social inequality, trauma, poverty of the population, middle class, precariat
\end{abstract}

\section{INTRODUCTION}

For the first time in the new millennium, the world is faced with the global threat of a pandemic caused by the new SARS virus - CoV2. The disease dubbed the coronavirus infection COVID-19, which had its epicenter in Wuhan (China's Hubei province) moved to Europe on March 13, 2020. The World Health Organization described the situation as a pandemic on March 11, 2020. The disease developed rapidly, forcing the governments of most countries to take restrictive measures and quarantines. Although quarantine is based on the principles of proportionality and the use of the least restrictive ways [1, p. 329], it brought about a deterioration in the material situation of the masses of people, especially the lower median groups. From time to time in various regions, aerial and railroad connections between states were terminated, the work of enterprises was stopped, employees were transferred to a remote mode of work, etc. As a result, world trade is reduced, the economy is in crisis, the middle class is eroding, the level of poverty is growing, unemployment is growing rapidly, the units of the precariat are increasing. During this period, the role of the state in supporting the population naturally increases. Liberal ideas about the duty of the government to serve the global financial monopolies against its people are failing [2, p. 69]. The trauma caused by the coronavirus raises questions about the need to reduce social inequality. However, this is only possible if Russia becomes competitive and can make a technological breakthrough in the post-pandemic world. Economic growth will lead to a decrease in social inequality. But how can it be reached in Russia, traumatized, firstly, by the "shock therapy" of the 90s in XX century, which resulted in a sharp stratification of property and an escalation of unemployment; secondly, a sharp deterioration in the economic and social situation due to quarantine and restrictive measures during a pandemic? To get out of the state of social and infectious trauma, the government needs to implement "the main defining functions of regulation, planning, stimulation of economic processes in the country" [3, p. 46]. As the Korean researcher Chan Ha-Jun has shown in his work, almost all modern countries have become rich thanks to "recipes that directly contradict the principles of neoliberal economics" [4, p. 23]. A policy of planning economic and social development is needed to restore economic growth after the pandemic and reduce the income gap in Russia.

\section{RESEARCH METHODOLOGY}

The methodology is based on theoretical studies of inequality: the theory of stratification systems by O. I. Shkaratan [5], the factor theory of N. E. Tikhonova [6], the integrative approach of M. K. Gorshkov, Z. T. Golenkova [7;8]. The concept of trauma as applied to social reality is based on the results of traumatic social transformations' studies [9], deforming effects of culture [10], psychological trauma as negative memories of the past [11], the concept of trauma society as a new modality [12], 
a synergistic approach to trauma as the result of nonlinear changes in society [13].

\section{RESULTS OF THE STUDY}

The COVID-19 pandemic has caused enormous damage to the economies of all countries of the world, has caused infection of different ages' people [14], social status [15], exacerbated poverty and social inequality. Despite the quarantine measures, the total number of cases in the world by mid-October 2020 is 38 million 600 thousand people, and more than 1 million are dead. Representing primarily an infectious trauma, the new coronavirus infection, disrupting the human lifestyle, led to an economic crisis in most countries of the world, including Russia. Injuries in the form of an epidemic, as P. Sztompka noted, such as a "violation of normality", "disorganization in the order", unemployment, impoverishment, "violation of economic exchange" are "culturally traumatic events" [9, p. 9-10]. P. Shtompka believes that traumas are conquerable, but S. Kravchenko believes that traumas are an attribute of modern life [13].

The destructive effect of the injury also affected Russia. Society of trauma, which has developed in our country since the 90s, XX century, [12] as a result of the liberal policy's implementation has repeatedly experienced economic crises, recession, deformation of social life, a steady decline in living standards of the population, deepening poverty, as well as numerous "optimizations". Transformational processes in the social structure of society were the results of Post-Soviet Russian reforms. Modification in the social structure of society has had and has increased social inequality. The trauma inflicted by the policy of neoliberalism on the citizens of Russia was manifested in the degradation of industry, in the market use of minerals, the growth of unemployment, poverty, the formation of a precariat, and the outflow of capital abroad. As a result, Russia, pursuing a course of deindustrialization, has lost its technical and technological independence. [Ibid, p. 72]. These phenomena intensified during the years of the economic crisis of 2008 , as well as during the fight against the new coronavirus infection. Therefore, the repeated trauma inflicted by COVID-19 is especially hard for Russian society. The 2020 crisis will be much more devastating than in 2009.

In the scientific literature devoted to the social impact of the pandemic, two models of recovery from the expected recession are presented. The first model is based on a program of targeted assistance to the unemployed, lowincome people, increasing scholarships for students, subsidizing internships in companies for graduates, providing temporary support to small and medium-sized businesses. Undoubtedly, these measures are necessary, but not sufficient. Using such neoliberal technologies it is impossible to get out of the crisis.

The authors of another model believe that a reform of the social sphere is needed, "a radical change in the paradigm of the welfare state" [16, p. 59], and not minor repairs.
Researchers conclude that the Russian reforms, which will soon celebrate their 30th anniversary, demonstrate the belittling of "the role of state participation in solving key socio-economic and socio-cultural tasks [17, p. 232.] Aganbegyan writes about the need for a new socioeconomic policy, which should be based on national economic planning [18, p. 18], centralized state purchase of foreign equipment is required [Ibid, p. 38], and technologic update of all basic industries, raising the scientific and technological level to the developed countries of the world [Ibid, p. 40]. Russia needs a mixed economy, restoration of the welfare state [19, p. 76]. All financial receipts from Russian raw materials should be concentrated in the hands of the state [Ibid, p. 77]. These proposals can be implemented during a pandemic.

Flexible working conditions, which in the modern situation are the most common and beneficial for modern capitalism, do not only generate poverty. As G. Standing has shown, with the spread of flexible labor, inequality increases, the class structure changes, and a precariat appear [20, p. 19].

The neoliberal demand for a flexible labor market implies a reduction in labor costs [Ibid, p. eighteen]. The precariat is characterized by precarious employment, poverty, lack of guaranteed benefits, and benefits from the enterprise or the state in case of urgent need. What is the social contract that experts from the Higher School of Economics propose to introduce as a measure to reduce poverty by half? A social contract is a temporary measure of helping those in need to become self-sufficient over time. The social contract is concluded with a legal entity, and it should cover from 1.5 to 2.5 million people. But this is only a tenth of the poor in Russia. It would be more accurate to say that poverty will decrease by 2 million people, but not by half. After all, the poor in Russia, as stated in this report, from $16-18 \%$ of the total population. The introduction of a social contract without the state's activities for the development of the most important industrial production branches is a method of even greater precarization of the population in Russia.

\section{THE DISCUSSION OF THE RESULTS}

Today the world is struggling with a dangerous infectious disease transmitted from person to person. Becoming the seventh in the family of coronaviruses, COVID-19 has spread very quickly throughout most of the world, becoming a crisis for public health [21, p. 32]. Restrictions on attending meetings, school, university, as well as travel, leisure can become part of the "new norm" [22].

The social structure of modern Russian society, which has existed for more than 25 years in a market economy, is fundamentally different from the Soviet model. However, the researchers did not come to a consensus, firstly, about the criteria for distinguishing classes (strata) in Russia, and secondly, about the trends in social structure change during the fight against the pandemic.

M. I. Voeikov, G. V. Anisimova, based on the criterion of belonging to professional groups, distinguish three strata 
(classes): the bulk of workers, the creative class, and the elite (top managers) [23, p. 12]. From this differentiation, people cannot conclude about the incomes of certain strata. N. E. Tikhonova examines three strata of Russian society: upper, lower, and middle, noting that they correspond to the main criteria of classes in the interpretation of $\mathrm{M}$. Weber [6, p. 6]. We can agree with the author that the criterion for the selection of strata in Russia "in conditions of unrestrained commodification" was the material wellbeing of one or another stratum [24, p. 78]. M. K. Gorshkov also believes that the most relevant is income stratification. According to this criterion, he distinguishes seven main income groups in Russian society based on a median income of 15,000 rubles: wealthy, well-off, average income, median group, vulnerable, poor people, deep poverty [17, p. 234]. Thus, according to M.K. Gorshkov, the wealthy and well-off belong to the upper group, the median group is the middle group, and the vulnerable, the poor people, and deep poverty belong to the lower group.

What changes have occurred in the social structure of society during the pandemic, what changes will occur in the future? After all, the coronavirus COVID-19 will remain in the human population. Other potential infectious challenges may await humanity, which may be traumatic for states with weak economies. Analysts believe that inequality will increase between the top $20 \%$ and the bottom $80 \%$ both globally and in individual countries [25, p. 21]. In Russia, even before the pandemic, inequality rates were the highest on a global scale: $1 \%$ of wealthy people in Russia own $71 \%$ of the national wealth. In other countries, for example, in India, the corresponding indicator is $49 \%$, in the USA - 37\%, in China - 32\% [12, p. 43]. Other authors also note an increase in the number of oligarchs in Russia [26, p. 6]. Russia has no equal in the world between the group of the richest oligarchs and the multimillion poor population [Ibid, p. 26.] The incomes of the working citizens' majority in our country have stopped growing since 2012. As a result, by 2019 , the number of poor people increased by 9 million and reached a level of 21 million [27, p. 94]. The growth of poverty, the annual decline in the number, and the deterioration of the middle class's position in Russia are noted by AG Aganbegyan [18, p. 22]. Zh. T. Toshchenko writes about the fall in income of this class due to the significant growth since the 1990s. The cost of medical services, education, housing, which exceeded inflation [12, p. 121]. Thus, trauma as a result of regressive social changes in Russia existed before the pandemic in the form of a decrease in the incomes of the middle (group, class) and lower stratum. The precariat belongs to the lower layer, the ranks of which are constantly replenishing due to the deterioration of the middle layer's position. The pandemic only intensified and complicated this process.

The high-income inequality of Russian citizens as a result of the pandemic is recorded by experts from the National Research University "Higher School of Economics" under the leadership of Ya. I. Kuzminov. It is noted that the pandemic has reduced income per capita in average 9.7 $11.5 \%$. [28, p. 58]. Approximately $6.1 \%$ of the middle class ( $24 \%$ of the employed) due to the coronavirus crisis moved to the poor. Since March 2020, poverty in our country has grown to $20 \%$ of the total population. Lumpsum payments and other measures to support the population have reduced this figure to $16-18 \%$. However, in June 2020, the number of unemployed persons increased 3 times compared to March of the same year and amounted to 2.2 million people. Informally employed, as well as people employed in small businesses, whose labor income was 1.5 times the subsistence level, fell into the poor group as well [Ibid, p. 60].

What measures the experts of this report propose to reduce poverty and ensure income growth? They propose to expand the ranks of the middle class through the development of education, both higher and secondary technical, expand educational lending, subsidize internships in companies for university graduates, and update the activities of employment services. It also offers targeted assistance to poor families with children, an increase in social stipends to the subsistence level, and also supports citizens based on a social contract. [Ibid, p. 61-63]. How effective are these measures? These measures are aimed at temporarily reducing the percentage of poverty during a pandemic, and not at reducing the difference in income between representatives of different social classes. The main reason for poverty is cheap labor and the lack of enough jobs due to the liberal deindustrialization policy in Russia. The problem of low wages is urgent for Russia. Low-paid jobs lead to poverty of the population [29, p. 490].

Reducing the cost of labor, as researchers show [30, p. 3], reduces the personal income, brings together skilled and unskilled labor. Therefore, incentives to obtain an education are reduced. Even if a person is highly qualified, he may not find a job within the country that matches his qualifications. Entrepreneurs are not interested in introducing new technology, since low-skilled manual labor requires lesser payment. The cheapening of labor work leads to the emergence of "new poor" who, having a job income below the subsistence level, are forced to look for a part-time job [Ibid, p. 4-5].

During the pandemic, while the demand for labor decreases, a person will agree to any conditions of employment, even with lesser wages.

The state, to some extent, tried to compensate for the losses of citizens from the pandemic. The payments of the minimum unemployment benefit were increased from 1,500 rubles per month up to 4.500 rubles. The maximum amount of unemployment benefits was also raised from 8.000 rubles per month up to 12.130 rubles. Also, there were made payments for children under three years of age and lump sum payments for minor children in the amount of 10,000 rubles.

We can agree with the opinion of L. Yu. Grudtsyna that the measures taken by the government to support the population are insufficient [31, p. 21]. So the French government pays the unemployed $84 \%$ of their previous salary, small businesses in the Czech Republic receive interest-free loans, private entrepreneurs in Germany receive subsidies of up to 15 thousand euros [Ibid, p. 23]. 
Russia has taken anti-crisis measures to support small and medium-sized businesses. They include a tax deferral (for 6 months), loans for small and medium-sized businesses to resolve the issue of paying salaries to their employees, and other measures. However, the question arises about the possibility of paying taxes if the business did not work.

According to researchers, Russia can spend $3-4 \%$ of its GDP on fighting the consequences of the coronavirus [32, p. 122]. However, these payments will only compensate for the loss of income by the population by $2 \%$ [28, p. 58]. Other countries, for example, Australia, will spend about $10 \%$ of GDP, Canada - 6\%, Japan - 4.9\%, Kazakhstan 3.4\%. [32, p. 123]

In the Russian Economic Report, the World Bank predicts an increase in poverty due to the pandemic: under the scenario of moderate growth - from $12 \%$ to $14.8 \%$; under the extreme scenario - from $14.8 \%$ to $16.3 \%$. On average, thus, the growth of poverty in Russia will be $13.4 \%$. [33, p. 36]. The Report notes that the poverty rate is affected by the reduction in wages, unemployment. In April 2019, the unemployment rate in Russia was 4.7\%, and in April 2020 it rose to $5.8 \%$. During May 2020, unemployment crossed the $6 \%$ barrier, although in May 2019 it was $4.5 \%$ [Ibid, p. 32 ]. Aid to the needy is only $0.4 \%$ of GDP. The social security system needs to be improved. The amount of benefits is insufficient and barely covers one-third of income [Ibid, p. 38].

According to the forecast of the International Monetary Fund in 2020 due to the pandemic, all emerging market countries (Russia belongs to them) are forecast to have negative growth rates of per capita income. Low-income households will be affected more than others. Consequently, inequality will increase [34] despite social benefits and transfers. We can agree with the predictions of the authors [35, p. 25] that the liberal order will be optimized. The society "will be dominated by the mechanisms of social regulation at the level of national states, which control and redistribute an increasing share of public resources."

\section{CONCLUSIONS}

The conducted research shows that Russia has high social inequality in income. This type of inequality has begun since the formation of market relations, which was accompanied by a decrease in the level of mass consumption, a rise in the cost of living, and the uncontrolled privatization of the USSR advanced industry. The exploitation of the country's resources has become an income of the ruling class. Besides, the degradation of the industry has taken place, and the level of poverty is growing. For almost 30 years, the main population of Russia has been living in a state of social trauma. The pandemic has brought new trauma to Russia, both infectious and social. But the remnants of the public health system have allowed our country to avoid the worst scenarios of morbidity and mortality from the new coronavirus compared to some developed capitalist countries. Russia will go into recession like many other countries. The state in this difficult period supports the population, but fundamental changes in social relations are needed. Only a socially oriented economy led by the public sector can bring the country to the forefront of a new technological order and reduce the traumatic nature of social inequality.

Russia became the first country in the world to develop and register a vaccine against COVID-19, which will help humanity to defeat this dangerous disease. But this will be a new post-pandemic world.

\section{REFERENCES}

[1] Martin Cetron and Julius Landwirth, Publik Health and Ethical, Yale. Journal of Biology and medicine, 2005, № 78, pp. 325-330

[2] M.G. Delyagin, End of an era: be careful, doors open! General theory of globalization. Edition twelfth, revised and enlarged, IPROG, Book World, Vol. I, 2019, P. 832.

[3] V. N. Lavrov, T. V. Burtseva, K. S. Semenyuk, The main directions of improving the socio-economic wellbeing of the population of Russia, Bulletin of the Ural Institute of Economics, Management and Law, 2017, № 3 (40), P. 45-49.

[4] Chan Ha-Joon, The Evil Samaritans: The Myth of Free Trade and the Secret History of Capitalism. Per. from English A. Korobeinikova, scientific. ed. A. Smirnova, Mann, Ivanov and Ferber, 2018, P. 256.

[5] O.I. Shkaratan, Sociology of Inequality, Theory and Reality, Higher School of Economics Publishing House, 2012, P. 526.

[6] N.E. Tikhonova, Features of identities and worldview of the main strata of modern Russian society, World of Russia, 2020, T. 29, № 1, P. 6-30.

[7] M. K. Gorshkov, Russian society as it is (experience of sociological diagnostics), vol. 1, New chronograph, 2016, P. 416.

[8] An employee in modern Russia, Otv. ed. Z. T. Golenkova, New chronograph, 2015, P. 368.

[9] P. Sztompka, Social Change as Trauma, Sociological Research, 2001, № 1, P. 6-16.

[10] J. C. Alexsander, Cultural trauma and collective identity, In The meaning of social life: Cultural sociology, The Oxford University Press, 2003, P. 296.

[11] C. Caruth, Trauma, Explorations in Memory. Baltimore: Johns Hopkins University Press, 1995, P. 284.

[12] Zh. T. Toshchenko, Society of Trauma: Between Evolution and Revolution (the Experience of Theoretical 
and Empirical Analysis), Moscow, "Ves Mir", 2020, P. 352.

[13] S. Kravchenko, The birth of «normal trauma»: The effect of non-linear development, Economics and Sociology 2020, 13(2), pp. 150-159. DOI:10.14254/2071789X.2020/13-2/11

[14] H. Yoshikawa, A. J. Wuermli, P. R. Britto, B. Dreyer, J. F. Leckman, S. J. Lye, L. A. Ponguta, L. M. Ruchter, A. Stein, Effect of the Global Coconavirus Disease-19 Pandemicon on Early Childhood Development: Short - and Long-Term Risks and Mitigating Program and Policy Actions, Journal of Pediatrics, V. 223, August 2020, PP. 188-193.

[15] J. Tsai, M. Wilson, COVID-19: apotenial publik health problem for homeless populations, Lancet Public Health, 2020, Apr. 5 (4), pp. 186-187.

[16] E. S. Sadovaya, Concept and implementation of the idea of an unconditional basic income in the context of the transformation of the social and labor sphere, Social and labor research, 2020, № 1 (38), pp. 59-71.

[17] M. K. Gorshkov, Russian Society in the Sociological Dimension, Bulletin of the Russian Academy of Sciences, 2020, T. 90, № 3, pp. 232-242.

[18] A. G. Aganbegyan, On the need for a new socioeconomic policy, Central Russian Bulletin of Social Sciences, 2020, T. 15, № 3, pp. 15-50.

[19] B. Yu. Kagarlitskiy, The End of the Consumer Consensus, Free Thought, 2019, № 1 (1673), pp. 61-78.

[20] G. Standing, Precaria: A New Dangerous Class, Hell Marginem Press, 2014, P. 328.

[21] F. Chen, M. Zhang, Y. Liu, Y. Zhang, K. Zhang, D. Su, X. Meng, Y. Zhang, The characteristics and outcomes of 681 severe cases with COVID-19 in Chine, Yournal of Critical Care, 2020, № 60, pp. 32-37.

[22] P. R. Ward, A sociology of the Covid-19 pandemic: A commentary and research agenda for sociologists, Journal of Sociology, 2020, 20 July, pp. 1-10.

[23] M. I. Voeikov, G. V. Anisimova, Modern state: social structure and social inequality, Vestnik MFYuA, 2020, № 4, pp. 7-20.

[24] N. E. Tikhonova, Social structure of Russia: theories and reality, New Chronograph: Institute of Sociology RAS, 2014, P. 408.

[25] Yu. N. Silaev, N.P. Protsenko, Modernism Again? COVID-19 returns the state to its original nature, International Analytics, 2020, T. 11 (1), pp. 11-26.
[26] O. I. Shkaratan, Socio-economic inequality in the modern world and the emergence of new forms of social stratification in Russia, World of Russia, 2018, T. 27, № 2, pp. 6-35.

[27] Zh. T. Toshchenko, General and specific criteria for precarious employment (experience of empirical analysis), Sociological research, 2020, № 9, pp. 90-102.

[28] Russia in a new era: the choice of priorities and goals of national development: expert. Report Ya. I. Kuzminov (head of the editorial board; P. V. Orekhin, P. N. Netreba (editor-in-chief), National Research University "Higher School of Economics", Publishing House of Higher School the economy, 2020, P. 112.

[29] V. Ye. Gimpelson, R. I. Kapelyushnikov, A. V. Sharunina, Low-paid jobs in the Russian labor market: is there a way out and where does it lead? HSE Economic Journal, 2018, T. 22, № 4, pp. 489-530.

[30] R. M. Nizhegorodtsev, Innovative development of the economy and problems of the development of the labor market in Russia (instead of the preface), Labor and educational services markets in Russia: realities and prospects: Monograph, INFRA-M, 2016, P. 324.

[31] L. Yu. Grudtsyna, "A New Deal for a Forgotten People": a Plan of Economic Support for Small Business as the Basis of State Support for the People, Education and Law, 2020, № 2, pp. 21-23.

[32] E. V. Lisova, Impact of COVID-19 on the socioeconomic activities of the regions. Entrepreneur's Guide, 2020, T. 13, № 20, pp. 119-125.

[33] Recession and growth amid the pandemic. Russian Economic Report, No. 43, July 2020 p. 36, Electronic resource, 10.10.2020.

[34] World Economic Outlook Update, June 2020, Electronic resource, 10.10.2020.

[35] V. S. Martyanov, L. S. Fishman, After the coronavirus: from an optimized old to a new world, Free Thought, 2020, № 3 (1681), pp. 9-28. 